\title{
The Carotenoids of Corynebacterium fascians Strain 2 Y
}

\author{
By J. PREBBLE \\ Bedford College, Regent's Park, London, N.W. I \\ (Accepted for publication 15 November 1967)
}

SUMMARY

An analysis of the carotenoids of Corynebacterium fascians, strain $2 \mathrm{Y}$, showed the presence of 13 fractions. The main pigments identified were $\beta$-carotene, a $\beta$-carotene-like fraction (possibly $\beta$-isorenieratene), leprotene, a mono-hydroxy pigment, $\mathrm{P} 450$, a second xanthophyll, $\mathrm{P} 452$ and a glucoside of hydroxy-chlorobactene. The minor constituents have been identified as phytoene, phytofluene, $\beta$-zeacarotene, neurosporene, $\zeta$-carotene, lycopene and either $\gamma$-carotene or chlorobactene. $\mathrm{P} 452$ forms a purple derivative with an absorption maximum at $560 \mathrm{~m} \mu$ in the presence of calcium salts which can be converted to the original $\mathrm{P} 452$ form by treatment with traces of acid or alkali. The total carotenoid content of the organisms is estimated at between 0.5 and $0.6 \mathrm{mg}$. carotenoid/g. dry weight of organism.

\section{INTRODUCTION}

The corynebacteria include a number of highly pigmented organisms. Analyses of the pigments in Corynebacterium michiganense (Saperstein \& Starr, I954; Saperstein, Starr \& Filfus, 1954), C.poinsettiae (Starr \& Saperstein, 1953), C. erythrogenes (Hodgkiss, Liston, Goodwin \& Jamikorn, 1954) and a Corynebacterium sp. (Hodgkiss et al. 1954) have shown the pigmentation to be due to carotenoids which, from C. michiganense, have been isolated in a complex with protein (Saperstein \& Starr, 1955). A function for carotenoid pigments of bacteria in inhibiting lethal photooxidations was shown initially in photosynthetic organisms (Stanier \& Cohen-Bazire, 1957) and later in non-photosynthetic bacteria (see, for example, Mathews \& Sistrom, 1959, 1960; Mathews \& Krinsky, 1965; Roth, 1967) including Corynebacterium poinsettiae (Kunisawa \& Stanier, 1958). Although protection against photo-oxidations is the only known function of carotenoids in non-photosynthetic bacteria, the carotenoids present in the organisms so far examined appear to differ widely from species to species; however, the number of species examined in any one group is very limited. The present paper describes the carotenoid pigments of a further species, Corynebacterium fascians. A preliminary report of the pigments found in C. fascians has already been published (Prebble, 1962), but a closer investigation of this organism has shown the carotenoids present to differ slightly from those originally described. In particular, the pigments cryptoxanthin and zeaxanthin were incorrect identifications for two related but apparently hitherto undescribed carotenoids designated $P_{450}$ and $P_{452}$. Also, the pigments originally believed to be forms of $\beta$-carotene are probably three unrelated pigments. 


\section{METHODS}

Strain $2 \mathrm{Y}$ (isolated by Mohanty, 195I) of Corynebacterium fascians (Tilford) Dowson was grown on a medium containing (\%, w/v) 3 mannitol, $0.2 \mathrm{NH}_{4} \mathrm{Cl}, 0.2$ asparagine, $0 . \mathrm{I}$ glycine, $0 . \mathrm{I}$ valine, $0.000 \mathrm{I}$ thiamine, $0.5 \mathrm{KH}_{2} \mathrm{PO}_{4}, 0.5 \mathrm{Na}_{2} \mathrm{HPO}_{4}$, $0.02 \mathrm{MgSO}_{4}, 0.0 \mathrm{I} \mathrm{NaCl}, 0.000 \mathrm{I} \mathrm{FeCl}, 2$ agar; incubated at $26^{\circ}$ for 4 days. The organisms were scraped from the agar and repeatedly extracted with methanol until no further appreciably coloured extract was obtained.

For direct separation on alumina columns, $20 \%(\mathrm{v} / \mathrm{v})$ water was added to the methanol before exhaustive extraction with light petroleum (b.p. $40-60^{\circ}$ ) followed by ether to remove the more polar pigments. Additions of acetone were made to break emulsions. The petroleum extract was washed with water, dried over $\mathrm{Na}_{2} \mathrm{SO}_{4}$, and evaporated to small volume under nitrogen. Hypophasic and epiphasic fractions were obtained by partition of the petroleum solutions with $90 \%(\mathrm{v} / \mathrm{v})$ methanol in water.

Saponification was done overnight at room temperature $\left(18^{\circ}\right)$ in the dark after the addition of half a volume of $33 \%(\mathrm{w} / \mathrm{v}) \mathrm{KOH}$ in methanol to the crude methanol extract.

Fractionation of extracts was achieved mainly on alumina columns of various Brockmann activities; I and 2 were obtained from Hopkin \& Williams, Chadwell Heath, Essex, while the lower activities were prepared according to Brockmann \& Schodder (I94I). Pigment preparations were placed on alumina columns in petroleum and the pigments were eluted with increasing concentrations of ether, acetone and ethanol in light petroleum. Calcium carbonate and zinc carbonate columns were used for the separation of the more polar pigments.

Isolated carotenoids were chromatographed with standards on thin layers of alumina by using mixtures of acetone $(5-20 \%, \mathrm{v} / \mathrm{v})$ in light petroleum for development.

The major carotenes were treated with iodine under illumination to form cis-isomers and isomers of dehydro- $\beta$-carotene (isocarotene) (Polgar \& Zechmeister, 1942; Zechmeister \& Wallcave, I953).

A quantitative estimation of the sugar present in fraction $\mathrm{P} 462$ was made by the method of Park \& Johnson (1949); as standard, a sample of glucose treated in the same manner as the carotenoid was used. Concentrated $\mathrm{HCl}(0.2 \mathrm{ml}$.) was added to I ml. methanolic carotenoid solution and the hydrolysis done at $60^{\circ}$ for $20 \mathrm{~min}$., I $\mathrm{ml}$. water was then added and the solution extracted with light petroleum to remove carotenoid components. The aqueous preparation was adjusted to between $\mathrm{pH} 10.5$ and $I \mathrm{I} \cdot \mathrm{O}$ and the reducing sugar estimated.

Identification of the sugar was by means of thin-layer chromatography. After hydrolysis and removal of carotenoid, the preparation was de-ionized in an electrolytic de-ionizer, evaporated to small volume under reduced pressure and chromatographed on Kieselguhr G-sodium acetate plates according to the method of Stahl \& Kaltenbach (I96I). Under these conditions glucose gave two spots, because of some degradation.

Samples of standard carotenoids were obtained from Koch-Light Laboratories Ltd., Colnbrook, Bucks. (synthetic $\beta$-carotene), Professor Weedon's laboratory (leprotene, hydroxy-chlorobactene and 4 -hydroxy- $\beta$-carotene) and Dr B. Gilchrist (3-hydroxy- $\beta$-carotene). Preparations of carotenoids were made from maize seedling leaves ( $\beta$-carotene), tomatoes (lycopene) and rose hips from Rosa canina (rubixanthin). 


\section{RESULTS}

Extraction of carotenoid from bacteria grown on the mannitol-valine-glycineasparagine medium gave a yellow solution with a maximum absorption in methanol at $458 \mathrm{~m} \mu$. Assuming an $E_{1 \mathrm{~cm}}^{1 \%}$ value of 2500 , these cultures contained between 0.5 and $0.6 \mathrm{mg}$. carotenoid $/ \mathrm{g}$. dry wt. bacteria. Preliminary experiments with a simplified mannitol (I \%) asparagine-salts medium showed that this concentration of carotenoid was sensitive to environmental conditions. Static liquid cultures having a poor oxygen

Table I. Chromatography of the total pigment extract of Corynebacterium fascians strain $2 Y$ on an alumina column (Brockmann activity 2)

\begin{tabular}{|c|c|c|c|c|c|c|}
\hline \multirow{3}{*}{$\begin{array}{l}\text { Band } \\
\text { I. Colourless with bluish- } \\
\text { green fluorescence } \\
\text { 2. Orange }\end{array}$} & \multicolumn{3}{|c|}{$\begin{array}{l}\text { Approximate } \\
\text { absorption } \\
\text { maxima }(\mathrm{m} \mu)\end{array}$} & \multirow{2}{*}{$\begin{array}{l}\text { Elution solvent } \\
4 \%(v / v) \text { ether in } \\
\text { light petroleum }\end{array}$} & \multirow{2}{*}{$\begin{array}{c}\text { Phase partition } \\
\text { between light } \\
\text { petroleum and } \\
90 \%(\mathrm{v} / \mathrm{v}) \\
\text { methanol } \\
\text { in water } \\
\text { Epiphasic }\end{array}$} & \multirow{2}{*}{$\begin{array}{c}\text { Final carotenoid } \\
\text { identification } \\
\text { Phytoene, phytofluene }\end{array}$} \\
\hline & $\begin{array}{l}275 \\
333\end{array}$ & $\begin{array}{l}285 \\
350\end{array}$ & $\begin{array}{l}300 \\
369\end{array}$ & & & \\
\hline & $(428)$ & 450 & 477 & $\begin{array}{l}8 \%(v / v) \text { ether in } \\
\text { light petroleum }\end{array}$ & Epiphasic & $\beta$-carotene (all-trans) \\
\hline 3. Orange & 427 & 450 & 476 & $\begin{array}{l}15 \%(\mathrm{v} / \mathrm{v}) \text { ether in } \\
\text { light petroleum }\end{array}$ & Epiphasic & $\begin{array}{l}\text { 'Carotene } 450 \text { ' (? } \beta \text {-iso- } \\
\text { renieratene) }\end{array}$ \\
\hline 4. Orange & $(430)$ & 452 & 480 & $\begin{array}{l}20 \%(\mathrm{v} / \mathrm{v}) \text { ether in } \\
\text { light petroleum }\end{array}$ & Epiphasic & Leprotene, $\beta$-zeacarotene \\
\hline 5. Deep orange & . & 448 & . & $\begin{array}{l}5 \%(\mathrm{v} / \mathrm{v}) \text { acetone in } \\
\text { light petroleum }\end{array}$ & Epiphasic & $\begin{array}{l}\text { Neurosporene, } \gamma \text {-carotene } \\
\text { or chlorobactene, } \zeta \text { - } \\
\text { carotene, lycopene } \\
(\beta \text {-zeacarotene })\end{array}$ \\
\hline 6. Orange-yellow & . & 450 & (472) & $\begin{array}{l}10 \%(\mathrm{v} / \mathrm{v}) \text { acetone } \\
\text { in light petroleum }\end{array}$ & $\begin{array}{l}\text { Mainly hypo- } \\
\text { phasic }\end{array}$ & $\mathbf{P}_{450}$ \\
\hline $\begin{array}{l}\text { 7. Orange-yellow (with } \\
\text { occasional grey-blue } \\
\text { band) }\end{array}$ & . & 453 & . & $\begin{array}{l}5 \% \text { ethanol in light } \\
\text { petroleum }\end{array}$ & Hypophasic & $P_{452}\left(P_{560}\right)$ \\
\hline 8. Orange-red & . & 462 & 485 & $\begin{array}{l}\text { Firmly bound, only } \\
\text { partially eluted } \\
\text { with } \mathrm{HCl} \text {-methanol } \\
\text { mixtures }\end{array}$ & Hypophasic & $\begin{array}{l}\mathrm{P} 462 \text {, hydroxy-chloro- } \\
\text { bactene glucoside }\end{array}$ \\
\hline
\end{tabular}

supply synthesized substantially less pigment than comparable surface cultures on agar medium. The addition of certain substances to an agar medium promoted pigment synthesis; for example valine at $0.1 \%(\mathrm{w} / \mathrm{v})$ produced up to a $50 \%$ increase in pigment content while increases in mannitol from $\mathrm{I} \%$ to $3 \%$ had a similar effect.

Chromatography of a pigment extract on an alumina column (Brockmann activity 2) gave the eight fractions listed in Table I. Separation of the pigment extract into epiphasic and hypophasic fractions, followed by chromatography on alumina and zinc carbonate, respectively, showed that fractions $\mathrm{I}-5$ were epiphasic, 7 and 8 hypophasic, while 6 was mostly, though not entirely, hypophasic. Saponification, before partition and chromatography, produced no apparent change in the subsequent behaviour of the pigments, from which it was concluded that probably none of the pigments was present in an esterified form in this organism. 


\section{Epiphasic pigments}

Fractions 2-4 with spectra almost identical to that of $\beta$-carotene (see Table 2), ran very close together on the column and were difficult to separate completely from one another. Comparison of the spectral and thin-layer chromatographic properties of each fraction with samples of $\beta$-carotene indicated that fraction 2 was all trans- $\beta$ carotene. Fractions 3 and 4 are unlikely to be $c i s$-isomers produced as artifacts during the extraction procedure since they were present at high levels relative to fraction 2 (see Zechmeister, I962). However, cis-isomers of $\beta$-carotene have been found in nature (Suzuki \& Tsukida, 1959); attempts were therefore made to convert fractions 2-4 to common products using catalytic amounts of iodine under illumination. Fraction 2 gave rise to a mixture of isomers, none of which were identical with fractions 3 and 4 . Fraction 4 would not isomerize appreciably under the conditions used successfully with $\beta$-carotene. Fraction 3 reacted to form a range of products giving at least three spots on thin-layer chromatograms; this range did not coincide with the isomers obtained from $\beta$-carotene and did not include a spot corresponding to all-trans- $\beta$-carotene. Thus it is doubtful whether this fraction can be classed as a cis-isomer of $\beta$-carotene and it is therefore designated carotene 450 .

Fraction 4 differed from fractions 2 and 3 in its failure to react readily with catalytic amounts of iodine and in its low solubility in light petroleum. Grundmann \& Takeda (I937) isolated from Mycobacterium phlei a pigment closely resembling $\beta$-carotene. The structure of this pigment, leprotene, has been shown to differ from $\beta$-carotene mainly in having aromatic end rings (Jensen \& Weedon, 1964). Fraction 4 was shown to be identical with leprotene in its chromatographic and spectral properties and to resist isomerization under the conditions used here.

Fraction I running in front of $\beta$-carotene was resolved into two fractions by further chromatography on alumina. The more strongly adsorbed fraction gave a greenish fluorescence in ultraviolet radiation and had an absorption spectrum corresponding to phytofluene, while the more rapid fraction had spectral properties of phytoene.

During purification of the $\beta$-carotene and leprotene fractions, small quantities of a pale yellow pigment were isolated. This pigment had spectral and chromatographic properties which suggest its identity with $\beta$-zeacarotene.

Fraction 5 was a mixture of several carotenoids all present in low concentration. The mixture was analysed on weakened alumina columns (Brockmann activity 4). The first two closely associated constituents were separated by developing columns with increasing concentrations of ether in light petroleum $(\mathrm{I}-5 \%, \mathrm{v} / \mathrm{v})$ and were identified by their spectra as neurosporene and either $\gamma$-carotene or chlorobactene. The two latter pigments have identical spectra and similar chromatographic properties. Unfortunately the available amounts of these pigments did not permit a final identification. The third polyene, closely associated with pigment $\mathrm{P} 450$, was eluted with $20 \%$ ether and identified as $\zeta$-carotene. A lycopene-like fraction, more strongly adsorbed, was separated and behaved similarly to lycopene on thin-layer chromatography.

\section{Hypophasic pigments}

Three readily separable hypophasic fractions, all major constituents, were obtained. The first of these was eluted from alumina (Brockmann activity 2) with $20 \%(\mathrm{v} / \mathrm{v})$ acetone in light petroleum. Its adsorption on columns and its partition characteristics 
suggested that it was a monohydroxy pigment, while the spectral characteristics were not dissimilar to those of cryptoxanthin although the purified pigment had a main maximum at $477 \mathrm{~m} \mu$ in light petroleum (Table 2). Repeated rechromatography of this pigment resulted in a spectrum which differs from that of cryptoxanthin in two respects: the main maximum is at a wavelength less than $448 \mathrm{~m} \mu$ and there is a broad shoulder at about $472 \mathrm{~m} \mu$ but no second maximum (Fig. I). Thin-layer chromatography with samples of 3 -hydroxy- $\beta$-carotene and 4 -hydroxy- $\beta$-carotene showed that the corynebacterial pigment ran slightly in front of the two standards and well behind echinenone, the order of increasing adsorption being echinenone, the test pigment, 4 -hydroxy- $\beta$-carotene, 3 -hydroxy- $\beta$-carotene. The corynebacterial pigment was further differentiated from 4-hydroxy- $\beta$-carotene in its inability to react with $\mathrm{HCl} / \mathrm{chloroform}$. In view of the failure to determine the identity of this pigment it has been necessary to designate it as pigment $\mathbf{P} 450$.

Table 2. The absorption maxima of the main carotenoids in Corynebacterium fascians strain $2 Y$ in various solvents

Light petroleum

Carotenoid

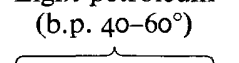

$\beta$-Carotene

Carotene 450

(? $\beta$-isorenieratene)

Leprotene

P 450

P 452

P 560

P 462

(hydroxy-chlorobactene glucoside)

\begin{tabular}{|c|c|c|c|c|c|}
\hline \multirow{2}{*}{ Ethanol } & $\begin{array}{l}\text { Carbon } \\
\text { disulphide }\end{array}$ & \multirow{2}{*}{$\begin{array}{c}\text { Chloroform } \\
-\end{array}$} & \multicolumn{3}{|c|}{ Benzene } \\
\hline & - & & & 465 & 493 \\
\hline- & - & - & $44 \mathrm{I}$ & 465 & 493 \\
\hline- & - & - & . & 464 & 492 \\
\hline 450 & 478 & $46 \mathrm{I}$ & . & 460 & \\
\hline 452 & 482 & $464(488)$ & . & 462 & . \\
\hline $566-57 \mathrm{I}$ & 580 & $573-574$ & . & 556 & . \\
\hline $46249 r$ & 494524 & 472501 & 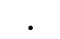 & 474 & 502 \\
\hline
\end{tabular}

The last pigment to be eluted with $5 \%$ ethanol in light petroleum from an alumina column also has a maximum at about $450 \mathrm{~m} \mu$ and is designated pigment $P_{452}$. On re-chromatography this carotenoid was found to have an absorption spectrum with a single peak at $449 \mathrm{~m} \mu$ and a very slight shoulder at about $480 \mathrm{~m} \mu$ in light petroleum (see Table 2). This spectrum does not correspond to either zeaxanthin or isozeaxanthin but resembles those of conjugated ketones (Fig. 2). However, reduction of the pigment with sodium borohydride gave a complex mixture of material absorbing at wavelengths about $400 \mathrm{~m} \mu$.

The most significant property of pigment $\mathrm{P} 452$ is its ability to form a purple derivative, designated $\mathrm{P} 560$, in the presence of calcium salts. A fresh pigment preparation placed on a calcium carbonate column in light petroleum became progressively bluer when adsorbed on the column and was eluted with 10\% acetone in light petroleum to give a purple solution having a spectrum with a broad maximum at about $560 \mathrm{~m} \mu$ (Fig. 2). The exact position of this absorption maximum varied considerably from preparation to preparation, probably due to isomerization, since a range of spots could be demonstrated by chromatography. The occasional occurrence of the purple form on alumina columns was presumably due to the presence of trace amounts of calcium hydroxide in the alumina. Pigment P 560 may also be formed by adsorbing pigment $\mathrm{P} 452$ on solid calcium hydroxide followed by treatment with a mixture of equal parts of pyridine and acetone; a purple solution is slowly obtained 
on standing. Pigment $\mathrm{P} 560$ is almost completely insoluble in light petroleum but readily soluble in acetone and ethanol. It is eluted from an alumina column with $10 \%(\mathrm{v} / \mathrm{v})$ acetone in light petroleum. The $\mathrm{P} 452$ form may be regenerated from $\mathrm{P} 560$ by gently shaking $\mathrm{I}$ petroleum solution with $0.1 \mathrm{~N}-\mathrm{HCl}$ in water or by treatment with methanol containing I $\%(\mathrm{w} / \mathrm{v}) \mathrm{NaOH}$.

The most strongly polar pigment present in Corynebacterium fascians, $\mathrm{P} 462$, was not eluted from an alumina column by normal solvent systems, and was best prepared by chromatography on zinc carbonate or calcium carbonate after partition between $90 \%(\mathrm{v} / \mathrm{v})$ methanol and light petroleum. It was eluted from these columns with $5 \%(\mathrm{v} / \mathrm{v})$ ethanol in light petroleum. The pigment was almost insoluble in petroleum and showed a strong affinity for sodium sulphate. The spectrum of a purified preparation shows a main maximum at $462 \mathrm{~m} \mu$ with a second peak at $49 \mathrm{r} \mathrm{m} \mu$ in ethanol and closely resembles that of the mono-hydroxy carotenoid, rubixanthin (Fig. 3,

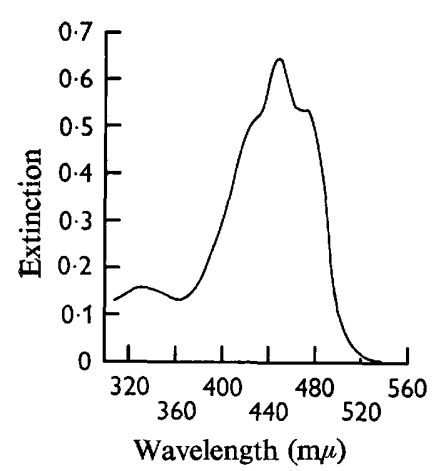

Fig. I

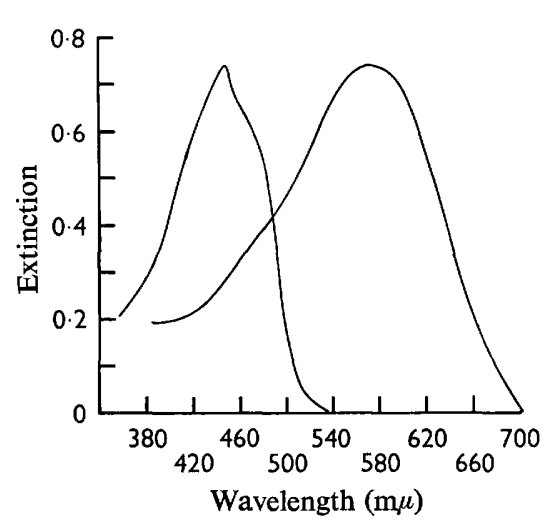

Fig. 2

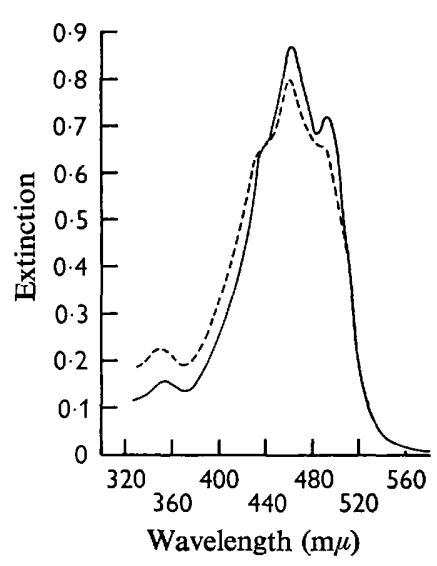

Fig. 3

Fig. I. Corynebacterium fascians strain $2 \mathrm{Y}$. The absorption spectrum of pigment $\mathbf{P} 450$ in light petroleum.

Fig. 2. Corynebacterium fascians strain $2 \mathrm{Y}$. The absorption spectra of pigment $\mathrm{P} 452$ in light petroleum (left-hand curve) and P 560 in ethanol (right-hand curve). P 560 was derived from $\mathrm{P} 452$ by adsorption on calcium hydroxide and elution with acetone and pyridine.

Fig. 3. Corynebacterium fascians strain $2 \mathrm{Y}$. The absorption spectra of pigment $\mathrm{P}_{462}$ (hydroxy-chlorobactene glucoside) in ethanol (-) and the pigment derived by acid hydrolysis of P 462 (hydroxy-chlorobactene) in ethanol (-- ).

Table 2). Saponification procedures had no effect on the nature of the pigment, but treatment with acid methanol $\left(20 \%, \mathrm{v} / \mathrm{v}\right.$, conc. $\mathrm{HCl}$ in methanol) for $\mathrm{ro} \mathrm{min.} \mathrm{at} 6 \mathrm{I}^{\circ}$ resulted in changes in the pigment's properties; the strongly hypophasic pigment became epiphasic. After this acid treatment the absorption spectrum remained essentially the same (Fig. 3) but the pigment now chromagraphed as a mono-hydroxy carotenoid. The mono-hydroxy carotenoids, rubixanthin and hydroxy-chlorobactene, have almost indistinguishable spectra with a main maximum at $46 \mathrm{I} \mathrm{m} \mu$. Both have been reported from bacteria, although Jensen, Hegge \& Jackman (1964) suggest that rubixanthin could be an incorrect identification for hydroxy-chlorobactene in many of the species from which it is reported. These two pigments may be separated on alumina layers using $15 \%(\mathrm{v} / \mathrm{v})$ acetone in light petroleum, the hydroxy-chloro- 
bactene being more strongly adsorbed than rubixanthin. The mono-hydroxy pigment from $C$. fascians was shown to be identical with, and inseparable from, hydroxychlorobactene on chromatography.

The result obtained on acid treatment suggests either extensive dehydration or, more likely, the hydrolysis of a strongly polar derivative of hydroxy-chlorobactene. The hypophasic layer was found to give a positive Molisch test. Estimation of the amount of reducing sugar produced from an arbitrary amount of pigment $\mathrm{P}_{462}$ gave a value equivalent to $6.9 \mu \mathrm{g}$, against an expected value of $6.8 \mu \mathrm{g}$, assuming an $E_{1 \mathrm{~cm}}^{1 \%}=2500$ for hydroxy-chlorobactene and the presence in each carotenoid glycoside molecule of a single residue of reducing hexose. The sugar was, in fact, identified as

\section{Table 3. The carotenoids of Corynebacterium fascians strain $2 Y$}

Estimates of the amount of each carotenoid present in the organism. It is assumed that during analysis the rate of oxidation of each pigment is the same. $E_{1 \mathrm{~cm}}^{1 \%}$ values are taken from Davies (I965) or, where not known, a value of 2500 has been used. In calculating the amount of carotenoid a value of $0.55 \mathrm{mg}$. $/ \mathrm{g}$. dry wt. organism was used.

\begin{tabular}{|c|c|c|c|c|}
\hline Carotenoid & $E_{1}^{\mathbf{~}} \%$ & $\lambda_{\max }$ & $\begin{array}{c}\% \\
\text { of total } \\
\text { pigment }\end{array}$ & $\begin{array}{c}\mu \mathrm{g} . \\
\text { carotenoid/g. } \\
\text { dry wt. } \\
\text { organism }\end{array}$ \\
\hline Phytoene & 1250 & 285 petroleum & $4 \cdot 8$ & 26 \\
\hline Phytofluene & I350 & 348 petroleum & $\mathrm{I} \cdot 9$ & 10.4 \\
\hline$\beta$-Carotene & 2505 & 45I petroleum & $8 \cdot 2$ & 45 \\
\hline Carotene 450 (? $\beta$-isorenieratene) & 2500 & 450 petroleum & $5 \cdot 2$ & 38 \\
\hline Leprotene (isorenieratene) & 2250 & 465 benzene & $24 \cdot 2$ & 133 \\
\hline$\beta$-Zeacarotene & 2570 & 428 hexane & $0 \cdot 7$ & $3 \cdot 8$ \\
\hline Neurosporene & 2990 & 440 petroleum & $0 \cdot 3$ & $1 \cdot 6$ \\
\hline$\gamma$-Carotene & 3100 & 462 petroleum & 0.6 & 3.3 \\
\hline$\zeta$-Carotene & 2270 & 400 petroleum & $1 \cdot 0$ & $5 \cdot 5$ \\
\hline Lycopene & 3450 & 472 hexane & 0.4 & $2 \cdot 2$ \\
\hline P 450 & 2500 & 450 petroleum & $16 \cdot 6$ & 9 I \\
\hline P 452 & 2500 & 450 petroleum & $20 \cdot 6$ & II3 \\
\hline $\begin{array}{l}\text { P 462, hydroxy-chlorobactene } \\
\text { glucoside }\end{array}$ & 2500 & 462 ethanol & $15 \cdot 7$ & 86 \\
\hline
\end{tabular}

glucose. It was found that the sugar derived from the carotenoid produced two spots on chromatography which were identical with those produced from standard glucose given the same acid treatment. It is therefore concluded that $P_{462}$ is a glucoside of hydroxychlorobactene.

Attempts have been made to hydrolyse $\mathrm{P} 462$ using enzymes. Neither maltase nor emulsin hydrolysed the carotenoid glucoside in ethanol-water mixtures where it was known that the enzyme would attack a standard substrate (cf. Smith, I963a; Hertzberg \& Jensen, 1967).

\section{DISCUSSION}

Evidence for the existence of 13 different carotenoid pigments in strain $2 \mathrm{Y}$ of Corynebacterium fascians has been presented. Estimates, based on extinction coefficients, of the relative and absolute quantities of the individual pigments are shown in Table 3. The principal constituents in this mixture are $\beta$-carotene; a $\beta$-carotene-like pigment, carotene 450 ; leprotene (isorenieratene); two apparently new xanthophylls, $\mathrm{P} 450$ and $\mathrm{P} 45^{2}$; and hydroxy-chlorobactene glucoside. The remaining pigments, present in low concentration, are probably all intermediates in the synthesis of the 
principal constituents. An earlier communication of the carotenoids of this organism failed to distinguish leprotene from $\beta$-carotene and identified pigments $\mathrm{P} 450$ and $\mathrm{P} 452$ with cryptoxanthin and zeaxanthin respectively. At this stage it was not realized that the purple pigment $P 560$ was derived from $P$ 452. This led to a carotenoid composition that had much in common with that of higher plants, now obviously an erroneous view.

Some of the pigments described require further comment. The carotene closely related to $\beta$-carotene, running slightly behind $\beta$-carotene on columns and thin layers, is probably a new pigment rather than a naturally occurring cis-isomer of $\beta$-carotene, for the following reasons. Iodine treatment of the pigment produced a group of substances similar to, but slightly less strongly adsorbed on alumina than, those formed from $\beta$-carotene, but no pigment corresponding to all-trans- $\beta$-carotene. In addition, the main absorption band of carotene- 450 is at a wavelength not less than that of $\beta$-carotene and the spectrum of the new carotene shows no cis-peak. It therefore seems appropriate to suggest that this may be a pigment intermediate in structure between leprotene and $\beta$-carotene. Such a pigment, $\beta$-isorenieratene, has been isolated, together with both $\beta$-carotene and leprotene, from Phaeobium by Jensen (I965a). Carotene- 450 has chromatographic and spectral properties identical with those described for $\beta$-isorenieratene (cf. Tables I, 2).

Of the three apparently new xanthophylls, $\mathrm{P} 450$ seems to be almost but not quite identical with 4 -hydroxy- $\beta$-carotene and hence would appear to be a mono-hydroxy pigment. The more strongly adsorbed pigment $\mathrm{P} 452$ is assumed to be a carotenoid on the basis of its spectrum, chromatographic properties and solubility in hydrocarbon solvents. However, it is significant in its ability to form a purple derivative in the presence of calcium salts. To my knowledge, no other naturally occurring pigment with this property has been described. Two carotenoids from invertebrates are known to form purple derivatives; actinioerythrin is believed to form a purple derivative after careful treatment with $\mathrm{NaOH}$ (Heilbron, Jackson \& Jones, 1935), while astaxanthin will form purple complexes with proteins (Cheesman \& Prebble, I966; Cheesman, Lee \& Zagalsky, 1967) and a purple derivative after treatment with potassium butoxide, which is believed to be a potassium salt. Neither of these pigments has been shown to react with calcium. It should be noted that there is no evidence at present that $\mathrm{P} 560$ contains any calcium although the properties suggest that it may be a calcium salt, in which case a pigment possessing two adjacent hydroxyl groups seems likely.

Naturally occurring carotenoid glycosides were unknown until Smith (I963a,b) described a neurosporyl glucoside from Mycoplasma. Subsequently two further glucosides have been thoroughly characterized from Mycobacterium phlei strain VERA by Hertzberg \& Jensen (1967). The hydroxy-chlorobactene glucoside described here is probably only one of many naturally occurring glucosides yet to be identified since strongly adsorbed pigments are not infrequently described in micro-organisms; for example, Hodgkiss et al. (1954) described a pigment, corynexanthin, from Corynebacterium species which resembles $\mathrm{P} 462$ in its chromatographic properties but has its main absorption maximum at $437 \mathrm{~m} \mu$ in ethanol. Smith suggested that the function of the neurosporyl glucoside of Mycoplasma was that of a permeability factor mediating glucose transfer across the membrane; a similar function here seems unlikely since the sole carbohydrate present in the medium is mannitol.

None of the corynebacteria investigated earlier were reported to contain either 
leprotene or the xanthophylls described here. Strains of Corynebacterium michiganense synthesize cryptoxanthin, lycopene, spirilloxanthin, $\beta$-carotene and canthaxanthin (Saperstein et al. 1954), while C.poinsettiae synthesizes cryptoxanthin, lycoxanthin, lycopene and spirilloxanthin (Starr \& Saperstein, 1953), although the presence of spirilloxanthin has since been denied (Jensen, 1965 b). C. erythrogenes contains neoxanthin, sarcinaxanthin and corynexanthin (Hodgkiss et al. 1954). Indeed a greater affinity with the leprotene-synthesizing Mycobacterium might be claimed, particularly since the mycobacterial xanthophylls B and C of Goodwin \& Jamikorn (I956) could be closely related to the xanthophylls of $C$. fascians. The problematical position of C. fascians and closely related Mycobacterium species was discussed by Gordon (I966), who suggested that there is no clear delineation of the two genera. It is therefore not surprising to find that the carotenoid composition of the strain $2 \mathrm{Y}$ of $C$. fascians has similarities with that of some Mycobacterium strains.

I wish to thank Professor B. C. L. Weedon (Queen Mary College, London) for supplying samples of leprotene, 4-hydroxy- $\beta$-carotene and hydroxy-chlorobactene, and Dr B. Gilchrist (Bedford College, London), for a sample of 3-hydroxy- $\beta$-carotene.

\section{REFERENCES}

BrockmanN, H. \& Schodder, H. (I94I). Aluminium-Oxyd mit abgestuftem Adsorptionsvermögen zur chromatographischen Adsorption. Ber. dtsch. chem. Ges. 74, 73.

Chebsman, D. F. \& Prebble, J. (I966). Astaxanthin ester as a prosthetic group; a carotenoprotein from the hermit crab. Comp. Biochem. Physiol. 17, 929.

Cheesman, D. F., Lee, W. L. \& Zagalsky, P. F. (1967). Carotenoproteins in invertebrates. Biol. Rev. 42, I3I.

Davies, B. H. (1965). Analysis of carotenoid pigments. In Chemistry and Biochemistry of Plant Pigments. Ed. by T. W. Goodwin. London and New York: Academic Press.

GoodwIN, T. W. \& JAMIKORN, M. (1956). Studies in carotenogenesis. 17, The carotenoids produced by different strains of Mycobacterium phlei. Biochem. J. 62, 269.

GoRDON, R. E. (1966). Some strains in search of a genus-Corynebacterium, Mycobacterium, Nocardia or what? J. gen. Microbiol. 43, 329.

Grundmann, C. \& TAKEDA, Y. (1937). Ein neues Bacterien-Carotinoid, Leprotin. Naturwissenschaften $25,27$.

Heilbron, I. M., Jackson, H. \& Jones, R. N. (1935). The lipochromes of sea anemones. I, Carotenoid pigments of Actinia equina, Anemonia sulcata, Actinoloba dianthus \& Tealia felina. Biochem.J. 29, 1384 .

HertzBerG, S. \& Jensen, S. L. (1967). Bacterial carotenoids. 20, The carotenoids of Mycobacterium phlei, strain VERA. 2, The structures of the phlei xanthophylls-two novel tertiary glucosides. Acta chem. scand. 21, 15.

Hodgkiss, W., Liston, J., Goodwin, T. W. \& JAmikorn, M. (1954). The isolation and description of two marine microorganisms with special reference to their pigment production. J. gen. Microbiol. II, 438.

Jensen, S. L. (1965a). Bacterial carotenoids. I8, Aryl-carotenes from Phaeobium. Acta chem. scand. 19, 1025 .

JENSEN, S. L. (1965b). On fungal carotenoids and the natural distribution of spirilloxanthin. Phytochem. 4, 925.

Jensen, S. L. \& WeEdon, B. C. L. (1964). The structure of leprotene. Naturwissenschaften 51, 482.

JENSEN, S. L., HegGe, E. \& JACKMAN, L. M. (I964). Bacterial carotenoids. I7, The carotenoids of photosynthetic green bacteria. Acta chem. scand. 18, 1703.

KunisaWA, R. \& Stanier, R. Y. (1958). Studies on the role of carotenoid pigments in a chemoheterotrophic bacterium, Corynebacterium poinsettiae. Arch. Mikrobiol. 3I, I46. 
Mathews, M. \& KRINSKY, N. I. (1965). The relationship between carotenoid pigments and resistance. to radiation in non-photosynthetic bacteria. Photochem. Photobiol. 4, 813.

Mathews, M. \& Sistrom, W. R. (1959). Function of carotenoid pigments in non-photosynthetic bacteria. Nature, Lond. $\mathbf{1 8 4}$, 1892.

Mathews, M. \& Sistrom, W. R. (1960). The function of carotenoid pigments of Sarcina lutea. Arch. Mikrobiol. 35, I39.

MoHANTY, U. (195I). Corynebacterium fascians (Tilford) Dowson: its morphology, physiology, nutrition and taxonomic position. Trans. Br. mycol. Soc. 34, 23.

PARK, J. T. \& Johnson, M. J. (1949). A submicrodetermination of glucose. J. biol. Chem. 18I, I49.

Polygar, A. \& ZeCHMEISTER, L. (1942). Isomerisation of $\beta$-carotene. Isolation of a stereoisomer with increased adsorption affinity. J. Am. chem. Soc. 64, I856.

Prebble, J. (1962). Carotenoid production in Corynebacterium fascians (Tilford) Dowson. Biochem. J. 85, I3P.

Rотн, M. M. (1967). Carotenoid pigments and photokilling by acridine orange. J. Bact. 93, 506.

SAPERSTEIN, S. \& STARR, M. P. (1954). The ketonic carotenoid canthaxanthin isolated from a colour mutant of Corynebacterium michiganense. Biochem. J. 57, 273.

SAPERSTEIN, S. \& StARR, M. P. (1955). Association of carotenoid pigments with protein components in non-photosynthetic bacteria. Biochim. Biophys. Acta 16, 482.

SAPERStein, S., StarR, M. P. \& Filfus, J. A. (I954). Alterations in carotenoid synthesis accompanying mutation in Corynebacterium michiganense. J. gen. Microbiol. 10, 85.

SMTr, P. F. (1963a). The role of sterols in the growth and physiology of pleuropneumonia-like organisms. In Recent Progress in Microbiology. Ed. by N. E. Gibbons, p. 51 8. Toronto: University of Toronto Press.

SMith, P. F. (1963b). The carotenoid pigments of Mycoplasma. J. gen. Microbiol. 32, 307.

Stahl, E. \& Kaltenbach, U. (I961). Dünnschicht-Chromatographie. VI. Spurenanalyse von Zuckergemischen auf Kieselgur G-Schichten. J. Chromatogr. 5, 35I.

Stanier, R. Y. \& COHEN-BAZIRE, G. (I957). The role of light in the microbial world: some facts and speculations. Symp. Soc. gen. Microbiol. 56.

StARR, M. P. \& SAPERSTEIN, S. (1953). Thiamine and the carotenoid pigments of Corynebacterium poinsettiae. Arch. Biochem. 43, 157.

SuzukI, N. \& TsuKIDA, K. (1959). Carotenoids of the flowers of Osmanthus fragrans. Chem. pharm. Bull., Tokyo 7, 133 .

ZeChMEISTER, L. (1962). Cis-trans Isomeric Carotenoids, Vitamin A and Aryl Polyenes. Vienna: Springer-Verlag.

ZeChMEISTER, L. \& WALlCAVE, L. (I953). A study of some cis-trans isomerie dehydro- $\beta$-carotenes J. Am. chem. Soc. 75, 534I. 